\title{
Biotechnology patenting caught between Union law and EPC law: European bundle patents, unitary patents and intentional harmonization of decisions in the internal market
}

\begin{abstract}
Rob J Aerts*
Director IP, Tigenix SAU, Tres Cantos - Madrid, Spain

Although in the European Union (the Union) the substantive rules for the patenting of biotechnological inventions are governed by Directive 98/44, the actual examination and grant of patents in Europe is provided by the European Patent Office (EPO), which is not part of the Union legal order and acts according to a non-Union legal instrument, the European Patent Convention (EPC). This hybrid situation results in legal uncertainty and can lead to partly inconsistent applications of patentability requirements, since the EPO is not bound to Union law and cannot refer questions to the Court of Justice of the EU (CJEU). Thus, there is no guarantee that the Union and Unified Patent Court (UPC) judiciaries, on the one hand, and the EPO judiciaries, on the other hand, will come to comparable conclusions regarding the patenting of identical biotechnological subject-matter in the Union, irrespective of whether it concerns a classic European patent or a unitary patent. However, the unitary patent is introduced in the framework of fostering the functioning of the internal market and ensuring undistorted competition, and it provides uniform protection. The CJEU has given a very limited interpretation only to this concept of uniformity, leaving room for inconsistent decisions. Hence, it would appear that only intentional, determined harmonization efforts of the diverse judiciaries involved can increase consistency between decisions of the Union and the non-Union legal systems, although the judiciaries are unrelated. This call for coherency becomes even more pressing with the establishment of the unitary patent. Given this complex situation it may be questioned whether in the Union the law-makers of Directive 98/44 can fully achieve their aim in regulating and harmonizing biotechnology patenting.
\end{abstract}

Keywords: biotechnology, patentability requirements, European patent, unitary patent, Directive 98/44, Regulation 1257/2012, harmonization

\section{INTRODUCTION - THE PATENTING OF BIOTECHNOLOGICAL INVENTIONS IN THE UNION}

The technical field of biotechnology plays a very important role in developments in medicine and agriculture in the European Union (the Union), and the protection of biotechnological inventions is of fundamental importance for the development of a

* The opinions expressed in this paper reflect the personal view of the author only. 
broad range of industries. Harmonized protection throughout the Union Member States is essential in order to maintain and encourage investment in the field of biotechnology. ${ }^{1}$ Therefore, there was a need for regulating the patentability of biotechnological subjectmatter within the Union by substantive rules of Union law, and Directive 98/44 on the Legal Protection of Biotechnological Inventions (Biotechnology Directive) of the European Parliament and the Council sets rules for the patentability, or the exclusion from patentability, of biotechnological materials and processes in the Union Member States. $^{2}$ The Directive provides the criteria for patentability of for instance gene sequences, human embryonic stem cells, and processes for the production of plants or animals that involve steps of crossing and selection. In fact, biotechnology is the single technical field for which Union law provides explicit substantive rules for the patentability, or the exclusion from patentability, of subject-matter. The rationale of this specific governance by Union law is that the Union law-makers wanted to secure harmonized protection of biotechnological inventions in the internal market on the one hand, while at the same time safeguarding very sensitive ethical issues with respect to biotechnological inventions on the other hand. ${ }^{3}$

Although the Biotechnology Directive regulates the patenting of biotechnological subject-matter in the Union Member States, the actual examination and grant of a conventional European bundle patent (classic European patent) or a European patent with unitary effect (unitary patent) operative for participating Union Member States, is governed by the European Patent Convention (EPC), which convention created the European Patent Organization. ${ }^{4}$ Also, any post-grant opposition procedure with respect to a classic European patent or a unitary patent is governed by the EPC. This convention is an intergovernmental treaty, and it has no connection with Union law. Both Union Member States and non-Union states are contracting states to the EPC.

In order to harmonize European patent law, provisions of the Union's Biotechnology Directive providing specific patentability criteria for biotechnological products and processes were taken over in literal wording into the EPC. ${ }^{5}$ Thus, Biotechnology Directive Article 5(3) on the requirement for patentability of gene sequences, and Directive Article $6(2)$ (c) on exclusion from patentability of uses of human embryos for industrial or commercial purposes, and Directive Article 2(2) on exclusion from patentability of processes for the production of plants or animals that are essentially biological (i.e. involving crossing and selection), were all taken over in literal wording in the Implementing Regulations to the EPC, respectively in Rules 29(3), 28(c) and 26(5).

1. Directive 98/44/EC of the European Parliament and of the Council of 6 July 1998 on the legal protection of biotechnological inventions, O.J. 30 July 1998, L 213/13-21, Preamble 1, 3. 2. Directive 98/44/EC, note 1 above.

3. Directive 98/44/EC, note 1 above, Preamble 5; RS Crespi, 'The biotechnology patent directive is approved at last!' (1999) 17 Trends in Biotechnology 139; I Schneider, 'Governing the patent system in Europe: the EPO's supranational autonomy and its need for a regulatory perspective' (2009) 36(8) Science and Public Policy 619.

4. Convention on the grant of European patents of 5 October 1973, revised by Acts of 17 December 1991 and 29 November 2000, text as adopted by decision of the Administrative Council of 28 June 2001; Regulation 1257/2012 of the European Parliament and of the Council of the EU of 17 December 2012 on implementing enhanced cooperation in the area of the creation of unitary patent protection, O.J. 2012, L 361/1-8.

5. Notice dated 1 July 1999 concerning the amendment of the Implementing Regulations to the European Patent Convention OJ EPO 8-9/1999, 573-582; EPC rr. 26 to 29. 


\subsection{The patenting of biotechnological inventions is determined by a hybrid system}

The taking over of rules from the Biotechnology Directive into the EPC, however, does not mean that Union law was implemented in the EPC. ${ }^{6}$ In Opinion 1/09, the Court of Justice of the EU (CJEU) decided that the only guardians of the Union legal order are courts and tribunals of Union Member States in collaboration with the CJEU, to which Court questions on the interpretation of Union law are made by judiciaries of the Union Member States. ${ }^{7}$ The European Patent Office (EPO) established under the EPC for the purpose of examining patent applications and granting patents, and its judicial bodies ultimately testing the law, the Boards of Appeal, are part of a legal order that is separated from the Union legal order. ${ }^{8}$ Boards of Appeal are institutionally and judicially outside of the Union legal framework; they have a distinct legal personality under international law and they cannot take the place of courts and tribunals of Union Member States. ${ }^{9}$ Consequently, it is impossible for the Boards to refer questions on the interpretation of Union law such as the Biotechnology Directive to the CJEU. ${ }^{10}$ Boards of Appeal apply EPC law, and decisions by the CJEU about biotechnology patenting are not legally binding on either the Boards of Appeal or the EPO. ${ }^{11}$ In contrast, courts and tribunals of Union Member States can (or, given the circumstances, must) refer questions on the interpretation of provisions of the Biotechnology Directive to the CJEU, and rulings of the CJEU are binding on those courts and tribunals. ${ }^{12}$

It thus appears that the substantive law for patenting biotechnological inventions in the Union Member States is governed by a hybrid system comprising a Union Member State route and an EPO route. This hybrid system involves separate judicial bodies that ultimately decide on the patentability, or the exclusion from patentability, of biotechnological subject-matter. This is an exceptional situation called forth by the fact that biotechnology is the only technical field for which Union law provides substantive rules for patentability of subject-matter. Patentability in other technical fields in Europe, for instance chemistry, mechanical engineering or electricity, is governed solely by the rules of the EPC. It should be noted that the situation in the Union differs from that in the US, where the US Supreme Court can ultimately rule on broad statutory questions of patent eligibility. ${ }^{13}$

6. Cf. Opinion 1/09, European and Community Patents Court, EU:C:2011:123; RJ Aerts, 'The patenting of biotechnological inventions in the EU, the judicial bodies involved and the objectives of the EU legislator' (2014) 36(2) European Intellectual Property Review 88.

7. Art 19(1) TEU; Art. 267 TFEU; Opinion 1/09, note 6 above, para 66; Judge Allan Rosas of the Court of Justice noted that Opinion 1/09 is of constitutional significance and one of the most important decisions of the past ten years, since it emphasizes the role of national Union judiciaries in the Union judicial system, see <http://ipkitten.blogspot.nl/2014/04/fordhamreport-2014-european-unitary.html> (accessed 26 June 2014).

8. Boards of Appeal and the Enlarged Board of Appeal are set up within the EPO (Art 15 EPC).

9. Cf. Opinion 1/09, note 6 above, paras $71,79,80,84,85$.

10. Decision G 2/06, Stem Cells (WARF), ECLI:EP:BA:2008:G000206.20081125, reasons 11. 11. Art 23(3) EPC; Decision T 2221/10, Culturing Stem Cells (Technion), EP:BA:2014: T222110.20140204, reasons 38; Prosecution file of EP 1948791, Communications of 16 July 2014 and 26 August 2014; Decision G 2/02, Priorities from India (Astrazeneca), ECLI:EP: BA:2004:G000202.20040426, reasons 8.6.

12. Art 267 TFEU.

13. See for instance Association for Molecular Pathology v Myriad Genetics, Inc., No. 12-398 (Supreme Court 13 June 2013) and Mayo Collaborative Services v Prometheus Laboratories, Inc., 132 S. Ct. 1289 (2012). 
It is the purpose of the present article to investigate the legal and legislative consequences of having to operate with a dual system dealing with biotechnology patenting in the Union. Thus, the effects of the present hybrid situation on legal certainty will be examined. Then, it will be investigated whether this hybrid system with respect to biotechnology patenting is also part of the legislative package establishing the unitary patent in the Union. Finally, it will be assessed what the impact of the hybrid system is on consistency of application of patentability requirements, on legal certainty with respect to biotechnology patenting in the Union, and on overall effectiveness of control over biotechnology patenting by the Union legislators of the Biotechnology Directive.

\section{THE HYBRID SYSTEM CAUSES LEGAL UNCERTAINTY AND LACK OF CONSISTENCY REGARDING BIOTECHNOLOGY PATENTING}

With respect to both classic European patents and unitary patents, two different and separate legal systems evaluate the requirements for, and exclusion from, patentability of biotechnological subject-matter in the Union, of which one system includes the possibility of referring questions to the CJEU and is bound by CJEU decisions (the Union legal system), whereas the other system has no link with the CJEU and is not bound by CJEU decisions (the EPC legal system). Also, the two legal systems exert their influences during different time windows of examination and grant proceedings of classic European patents and unitary patents. Firstly, decisions concerning the patenting of biotechnological inventions remain solely within the EPC sphere prior to the granting of a patent during ex parte procedures before the Examining Division of the EPO, possibly including the appeal of a decision of the Examining Division to the Boards of Appeal. Also during inter partes opposition procedures before an Opposition Division and possible opposition appeal before the Boards of Appeal, the validity of patents is evaluated entirely according to the rules of the EPC. During these procedures, claimed subject matter may be refused, revoked or amended. Secondly, only after these internal EPO procedures, the rules of the Biotechnology Directive can be directly applied by Union judiciaries to test the validity of classic European patents or unitary patents during litigious proceedings.

In sharp contrast to classic European patents and unitary patents, when assessing the patentability of national Union Member State patent applications or patents, national Union courts and tribunals can immediately apply the Biotechnology Directive and refer questions to the CJEU. ${ }^{14}$ Thus, under various circumstances and during different time windows, two legal systems are involved in biotechnology patenting in the Union, but there is no guarantee that decisions made by the two separate legal systems about the conditions for patentability of biotechnological subject-matter result in similar, harmonized conclusions, and this situation causes legal uncertainty in the Union.

\subsection{Human embryonic stem cells and patenting in the Union}

The field of the patenting of human embryonic stem cells provides a striking example of legal uncertainty and variation in application of patentability requirements. Upon referral of a question by the German Federal Supreme Court (Bundesgerichtshof), the CJEU elaborated in the Brüstle decision (C-34/10) for the first time on the

14. See for instance prosecution of DE19756864, GB0621068.6 and GB0621069.4. 
scope of the definition of the term 'human embryo' in Article 6(2)(c) of the Biotechnology Directive, which provision excludes from patentability uses of human embryos for industrial or commercial purposes. ${ }^{15}$ Patent applications by International Stem Cell Corporation (ISCC) concerning pluripotent human embryonic stem cells resulted in a second referral of a question to the CJEU, and here the opinions on patentability of the Union and the EPO institutions differed widely. Two national UK patent applications by $I S C C$ resulted in the referral by the UK High Court of a question to the CJEU in case C-364/13 whether parthenotes containing only pluripotent cells that are incapable of developing into human beings are included in the term 'human embryo' according to Article 6(2)(c) of the Biotechnology Directive. ${ }^{16}$ The Advocate-General opined that parthenotes are not included in the term 'human embryo', and as such are not caught by the patentability exclusion, and in principle are patentable subject-matter. ${ }^{17}$ The patentability of parthenotes was affirmed by the CJEU in $2014 .^{18}$

With regard to two corresponding European patent applications by ISCC concerning parthenotes, for one application prosecution was slow, but for the other application several Communications were delivered before the decision by the CJEU, and this examination procedure shows the confusing way in which the one legal system can react to developments in the other. In 2012 the EPO initially indicated its intension to reject the application under the EPC Rule corresponding to Article 6(2)(c) of the Biotechnology Directive (Rule 28(c) EPC), and, given the at that time still pending C-364/13 decision, the EPO remarked that the CJEU does not have jurisdiction to decide matters for the EPO. ${ }^{19}$ ISCC responded to the intention of the EPO to reject the European patent application by stressing that parthenotes cannot develop into a human being. ${ }^{20}$ Subsequently and while the C-364/13 decision was still pending, the Examining Division opined that parthenotes are excluded from patentability, and that although the EPO is not bound to CJEU decisions, the intention to reject the application was in compliance with the earlier Brüstle decision (C-34/10). In particular, the Examining Division opined that parthenotes, despite not being viable, nevertheless have human dignity and shall be regarded as human embryos pursuant to Rule 28(c) EPC. Furthermore, it was stated that there is no EPC provision allowing suspension of EPO proceedings because of a pending referral before the CJEU. ${ }^{21}$ ISCC responded by referring to the Opinion by the Advocate-General that had been issued in the referral concerning ISCC's national UK patent applications, and ISCC asked the EPO to take the developments before the CJEU in case C-364/13 into account. ${ }^{22}$ Finally, the Examining Division replied by stating that although the decision in case C-364/13 is not formally binding on the EPO, it is relevant. ${ }^{23}$

If $I S C C$ had opted directly only for the pan-European route for obtaining protection for its inventions via European patents, and if ISCC had not filed parallel national

\section{Case C-34/10, Brüstle v Greenpeace, EU:C:2011:669.}

16. International Stem Cell Corp v Comptroller General of Patents [2013] EWHC 807 (Ch,) in particular para 59; Case C-364/13, International Stem Cell Corporation (ISCC) v Comptroller General of Patents, EU:C:2014:2451; Parthenotes are artificially activated unfertilized egg cells. 17. Opinion of A.G. Cruz Villalon of 17 July 2014 in Case C-364/13, ISCC.

18. Case C-364/13, note 16 above.

19. Prosecution file of EP 1948791, Communication of 21 September 2012, para 7.6; cf. prosecution file of EP 2049043, Communication of 19 December 2013, paras 1.7, 1.8.

20. Prosecution file of EP 1948791, response by the applicant of 14 December 2012.

21. Ibid, Communication of 16 July 2014, paras 10.2, 10.3, 11.1, 11.2.

22. Ibid, response by the applicant of 19 August 2014.

23. Ibid, Communication of 26 August 2014. 
patent applications, ISCC's European patent applications would have been refused from the onset by the EPO and presumably there would have been no possibility for ISCC to obtain patent protection. Also, if ISCC had not repeatedly directed the attention of the Examining Division of the EPO to the developments before the CJEU, or if the referral of the question on the patentability of parthenotes to the CJEU had come at a later time than the examination before the Examining Division of the EPO, ISCC's European patent application would have been refused, and the right might have been lost irrevocably after a possible appeal. If rights are lost before the EPO, there is no means of redress possible to restore a European patent right before an independent Union court. This illustrates how extremely critical the choice of the route for applying for patent protection can be: the question whether a patent applicant can obtain claims in a straightforward manner in the Union apparently may vary with the route the applicant takes, namely a national route or the intergovernmental EPO route.

Meanwhile, despite the earlier statement by the EPO that the use of human parthenotes is considered to offend against human dignity, and sometime after the Opinion by the Advocate-General and the decision by the CJEU concerning the patentability of parthenotes, the Examining Division of the EPO has adjusted its practice in line with the $I S C C$ decision in the Union legal system. ${ }^{24}$ It is unclear whether the Boards of Appeal of the EPO will follow this practice as well, and, retrospectively from the moment parthenotes became available to the scientific community, it is possible that applicants have lost time and rights. ${ }^{25}$

\subsection{Essentially biological processes for the production of plants or animals and patenting in the Union}

Another factor contributing to legal uncertainty is the fact that Biotechnology Directive provisions governing the criteria for the patenting of biotechnological inventions in the Union and inserted in the EPC are sometimes duly taken into account by the EPO, but they may be ignored as well. The CJEU as a matter of course will always take those provisions of Union law into account. ${ }^{26}$ Article 53(b) EPC excludes from patentability essentially biological processes for the production of plants or animals. The term 'essentially biological process' is specified in Article 2(2) Biotechnology Directive by providing that a process is essentially biological if 'it consists entirely of natural phenomena such as crossing or selection'. A provision was inserted in the EPC with the same wording as Article 2(2) Biotechnology Directive, namely Rule 26(5) EPC. According to the Enlarged Board of Appeal of the EPO, Rule 26(5) did 'not give any useful guidance', and after consideration the Rule was ignored by the Board. The Enlarged Board instead decided to interpret the term 'essentially biological process for the production of plants' on its own authority. ${ }^{27}$ Despite the interpretation formulated by the Enlarged Board, it was noted by Board of Appeal 3.3.04 that the

24. De Clercq \& Partners, Newsletter December 2015, 4-5.

25. WO 03/046141 entitled 'Methods for making and using reprogrammed human somatic cell nuclei and autologous and isogenic human stem cells' and published on 5 June 2003.

26. Art 267 TFEU.

27. Decision in consolidated cases G $2 / 07$ and G 1/08, Essentially Biological Processes (Tomato I and Broccoli I), EP:BA:2010:G000207.20101209, EP:BA:2010:G000108. 20101209, reasons 4, 5. 
Enlarged Board has not provided a comprehensive and exhaustive definition of what is an essentially biological process. ${ }^{28}$

The final word in interpreting patentability provisions of the Biotechnology Directive in the Union is with the CJEU, and it is clear that for Union Member States the explanation of the term 'essentially biological process' can only be definitely provided, and thus legal certainty can be obtained, once the issue is referred in a preliminary ruling to the CJEU. Unlike the Enlarged Board of Appeal, the CJEU will likely take Article 2(2) Biotechnology Directive into account, and may diverge in its decision from the interpretation by the Enlarged Board since the CJEU uses different interpretive methods and sources of law, thereby setting other patentability criteria and possibly changing the patent landscape. ${ }^{29}$ Indeed, the Enlarged Board of Appeal decided that a step of a technical nature assisting in a crossing or selection process does not mean that the exclusion from patentability can be circumvented, and it was noted before that this reading by the Board may extend beyond Article 2(2) Biotechnology Directive, since this article specifies the exclusion only of processes consisting entirely of natural phenomena such as crossing and selection, which may possibly not entail processes involving sophisticated technical steps. ${ }^{30}$

In sharp contrast to the situation described above, with respect to the patentability of gene sequences, the applicable provision of the Biotechnology Directive, namely Article 5(3), inserted in identical wording in Rule 29(3) EPC, was duly taken into account by the EPO in its decisions. Thus, Board of Appeal 3.3.08 based its assessment of the industrial applicability of gene sequences specifically on Rule 29(3) EPC, and an extensive string of case law was established. ${ }^{31}$ These examples illustrate the remarkable inconsistency in the application by the EPO of provisions taken from the Biotechnology Directive and inserted in the Rules of the EPC, and in the absence of further harmonization measures this adds to legal uncertainty with respect to biotechnology patenting in the Union.

\subsection{Legal uncertainty with respect to the patenting of biotechnological inventions}

In the field of biotechnology patenting in the Union, the diverging decisions by the Union legal order and the EPC legal order, and the fact that Union law-derived provisions are sometimes taken into account by the EPO and sometimes not, result in legal

28. Decision T 1729/06, Seedless Watermelon (Syngenta), EP:BA:2014:T172906.20140917, reasons 19.

29. T Minssen and A Nordberg, "The impact of "Broccoli II" and "Tomatoes II" on European patents in conventional breeding, GMOs, and synthetic biology: the grand finale of a juicy patents tale?' (2015) 34(3) Biotechnology Law Report 81; cf. SJR Bostyn, 'Resolving the conundrum of the patentability of plants produced by an essentially biological process: squaring the circle?' (2013) 35(7) European Intellectual Property Review 383, at 391.

30. Decision in consolidated cases G $2 / 07$ and G 1/08, note 27 above, Order answer to question 2; C Brabin, 'Intellectual property law in the realm of biology: striking the right balance' (2014) 36(11) European Intellectual Property Review 687, at 691.

31. RJ Aerts, 'Biotechnological patents in Europe - functions of recombinant DNA and expressed protein and satisfaction of the industrial applicability requirement' (2008) 39(3) International Review of Industrial Property and Copyright Law 282; A Sharples, 'Industrial applicability for genetics patents: divergences between the EPO and the UK' (2011) 33(2) European Intellectual Property Review 72. 
uncertainty and a partial lack of consistency in the application of patentability criteria. Also, it ultimately implies lack of control by the legislators of the Biotechnology Directive in the field of biotechnology patenting, since the Union has no control over patenting procedures executed by an organization entirely outside of the Union legal order. It was noted before that the EPO is an autonomous organization which is not subject to judicial or meaningful political scrutiny by the Union. ${ }^{32}$ This absence of a link between the Union and EPC legal orders was also emphasized before by the Advocates-General of the CJEU, who stated:

[T] he decisions of the European Patent Office concerning patents can only currently be reviewed by the internal chambers of appeal created within the European Patent Office, excluding any judicial appeal before an external court. There is no possibility of the European Court of Justice ensuring the correct and uniform application of Union law to proceedings taking place before the chambers of appeal of the European Patent Office. ${ }^{33}$

\section{THE UNITARY PATENT AND UNIFORM PATENT PROTECTION IN THE FIELD OF BIOTECHNOLOGY}

The unitary patent (formally: European patent with unitary effect) will be operative for the combined territories of participating Union Member States, and is part of the multicomponent 'EU Patent Package'. ${ }^{34}$ This patent package is the result of long and complicated negotiations, and it does contain elements of compromise. The first component of the package is Regulation 1257/2012 establishing the unitary patent (Unitary Patent Regulation), which as a matter of course is an instrument of Union law. ${ }^{35}$ The Regulation, however, makes use of other legal systems, and the unitary patent concerns an EPC-based patent right; namely, after grant of a European patent according to the rules of the EPC, the patent does not become a bundle of national rights like a classic European patent, but instead can be registered as a unitary patent according to the Regulation, thereby providing unitary effect in the participating Union Member States, i.e. most of the Member States of the Union. ${ }^{36}$ In particular, the Regulation is a special agreement according to Part IX, Article 142 EPC, which provides for the possibility of introducing a patent with unitary character throughout the territories of several contracting states. Thus, the Regulation establishing the unitary patent defines that a granted European patent has unitary character throughout the combined territories of the participating Union Member States. ${ }^{37}$ Since the unitary patent is a granted European patent, it is prone to opposition procedures according to the rules of the EPC.

32. A Plomer, 'A unitary patent for a (dis)united Europe: the long shadow of history' (2015) 46(5) International Review of Industrial Property and Copyright Law 508.

33. Statement of Position by the Advocates General regarding Opinion 1/09 of 2 July 2010, para 71.

34. See <http://ec.europa.eu/growth/industry/intellectual-property/patents/unitary-patent/ index_en.htm> (accessed 15 July 2015).

35. Regulation $1257 / 2012$, note 4 above.

36. Regulation 1257/2012, note 4 above, Art 3(1); 25 Union Member States signed the UPC Agreement on 19 February 2013 and Art 18(2) of Regulation 1257/2012 provides that the Unitary Patent is applicable to Member States that have acceded to the UPC Agreement.

37. Regulation 1257/2012, note 4 above, Art 1(2). 
The second component of the patent package is Regulation 1260/2012 determining the translation arrangements applicable to unitary patents. ${ }^{38}$

The third component of the patent package is the agreement establishing the Unified Patent Court (UPC), a court system for the settlement of disputes concerning unitary patents as well as classic European bundle patents. ${ }^{39}$ This agreement is an instrument of international law, however it is an initiative of, and it is controlled by, the Union. Also, the provisions on direct infringement, indirect infringement and limitation of the unitary patent right are found by way of an incorporating referral in Articles 25-27 of the agreement establishing the Unified Patent Court, instead of in the Unitary Patent Regulation itself. ${ }^{40}$

The creation of the unitary patent is based on Article 118 of the Treaty on the Functioning of the EU (TFEU), according to which provision the Union law-makers 'shall establish measures for the creation of European intellectual property rights to provide uniform protection of intellectual property rights throughout the Union'. On the basis of Article 118 TFEU, Regulation 1257/2012 was adopted, thereby establishing the unitary patent which confers on its proprietor a right and that 'the scope of that right and its limitations shall be uniform'. ${ }^{41}$ The aim of the Unitary Patent Regulation is to make it possible 'to obtain uniform patent protection in the participating Member States'. ${ }^{42}$ Since in the Union Member States the patenting of biotechnological inventions is governed by an instrument of Union law, namely the Biotechnology Directive, if a granted unitary patent concerns a biotechnological invention, the term 'uniform protection' in Article 118 TFEU may suggest that under all circumstances consistent and invariable patentability criteria as provided by the Biotechnology Directive should be used throughout the combined territories of the participating Union Member States. With respect to identical biotechnological subject-matter concerning gene sequences, human embryonic stem cells and essentially biological processes for the production of plants or animals, the same patentability criteria should be applied and the fate of a unitary patent should be independent of the judiciary evaluating its validity. Given the diverse legal systems involved, where this kind of conformity is actually meant it may be questioned whether it can be ensured.

\subsection{The Unified Patent Court is bound by Union Law, and also the patent package comprises a hybrid system}

The UPC deciding on disputes concerning unitary patents and classic European patents is a court bound by Union law. This follows directly from Opinion 1/09 of the CJEU which concerned a draft agreement establishing an international patent litigation court supposedly including both Union and non-Union states. In Opinion 1/09, the CJEU decided that the draft agreement was not compatible with the Union Treaties, and that international agreements may not adversely affect the autonomy of the Union legal order, and may not

38. Regulation 1260/2012 of the European Parliament and of the Council of the EU of 17 December 2012 on implementing enhanced cooperation in the area of the creation of unitary patent protection with regard to the applicable translation arrangements. OJ 2012, L 361/89-92.

39. Agreement on a Unified Patent Court, OJ 2013, C 175/1-22.

40. W Tilmann, 'The compromise on the uniform protection for EU patents' (2013) 8(1) Journal of Intellectual Property Law \& Practice 78.

41. Regulation 1257/2012, note 4 above, Arts 5(1) and 5(2).

42. Ibid, Preamble 4. 
change the essential character of the function of the CJEU. ${ }^{43}$ In line with Opinion 1/09, in the agreement establishing the UPC it is provided that only Union Member States can accede to the agreement. ${ }^{44}$ The UPC is a court common to the Member States, it is subject to Union law obligations, it shall apply Union law in its entirety, and shall respect its primacy. ${ }^{45}$ The UPC shall cooperate with the CJEU and refer questions on the interpretation of Union law to the CJEU to ensure the correct application and uniform interpretation of Union law. Decisions of the CJEU are binding on the UPC. ${ }^{46}$

Thus, when the validity of a unitary patent concerning a biotechnological invention is examined before the UPC, this court applies the provisions of the Biotechnology Directive directly, and the court can, or given the situation is obliged to, ask the CJEU for a preliminary ruling on the interpretation of Biotechnology Directive provisions regarding patentability criteria of biotechnological inventions. ${ }^{47}$ In sharp contrast, when a unitary patent concerning exactly the same biotechnological invention is opposed before the EPO, the provisions on patentability criteria of the Biotechnology Directive are not directly applied, and preliminary questions regarding the criteria for the patentability of biotechnological subject-matter cannot be referred to the CJEU.

Thus, also the introduction of the unitary patent appears to be based on a hybrid system. When the UPC examines the validity of a unitary patent and a provision of the Biotechnology Directive is involved, this court can or must refer questions to the CJEU, for instance on what is the scope of the term 'human embryo' according to the Biotechnology Directive, but in contrast when the EPO investigates a unitary patent during an opposition procedure, it cannot refer questions to the CJEU on the interpretation of Union law, for instance on what precisely is included in the term 'human embryo' according to the Biotechnology Directive. Also, in its decisions the EPO may ignore provisions of the Biotechnology Directive implemented in identical wording in the rules of the EPC, for instance with regard to the definition of 'essentially biological process for the production of plants or animals', whereas the UPC is subject to Union law obligations and will apply the provisions of the Biotechnology Directive. Under these circumstances, there is no guarantee that decisions made by the two judicial bodies concerning the patentability of the same biotechnological subject-matter show similar conclusions. The partial inconsistency and legal uncertainty in the field of biotechnology patenting caused by the division of judicial powers over Union and EPC judiciaries will continue under the rules of the 'EU Patent Package' with the introduction of the unitary patent. A major difference, however, is that the unitary patent purportedly provides 'uniform patent protection' according to the Treaty provision on which the creation of the unitary patent is based, namely Article 118 TFEU. ${ }^{48}$ In its decision in the action for annulment of the Unitary Patent Regulation by the Kingdom of Spain, the CJEU has elaborated on the meaning of 'uniformity' of patent protection.

43. Opinion $1 / 09$, note 6 above, paras 75,76 .

44. Agreement on a Unified Patent Court, note 39 above, Art 2.

45. Ibid, Arts 1, 20.

46. Ibid, Art 21.

47. F Baldan and E Van Zimmeren, 'The future role of the Unified Patent Court in safeguarding coherence in the European patent system' (2015) 52 Common Market Law Review 1529, at 1566; M Alt and W Pors, 'The European Unitary Patent and the Unified Patent Court system filing and litigation strategies' (2014) International Comparative Legal Guides: Patents, Bird \& Bird LLP; Rule 26(1) EPC provides that the Biotechnology Directive 'shall be used as a supplementary means of interpretation'.

48. Cf. RJ Aerts, 'The unitary patent and the Biotechnology Directive: is uniform protection of biotechnological inventions ensured?' (2014) 36(9) European Intellectual Property Review 584. 


\subsection{The reasoning of the Court of Justice in the action for annulment of the Unitary Patent Regulation}

Some of the issues raised above were articulated in a much more general context by the Kingdom of Spain in its action for annulment of Regulation 1257/2012 establishing the unitary patent. This action was rejected by the CJEU in decision C-146/13. ${ }^{49}$ In its first plea in law, the Kingdom of Spain argued that the procedures of the EPO are not subject to judicial review to ensure correct and uniform application of Union law. In particular, decisions of the Boards of Appeal of the EPO are not subject to any form of judicial review. The CJEU held that the Regulation is a special agreement pursuant to Article 142 EPC, and does not affect the conditions for the grant of a European patent. The Regulation does not 'incorporate' the EPC procedure for the grant of European patents into Union law, but merely establishes the conditions under which such a granted patent can have unitary effect upon request. ${ }^{50}$ Thus, the CJEU strictly separated the procedures for grant of a European patent governed by the EPC, on the one hand, from the unitary effect added after grant and registration of a unitary patent as governed by Regulation 1257/2012, on the other hand. It is important to note that the CJEU in its decision did not address the issue of the EPO retaining competence outside the jurisdiction of the UPC - after grant of a unitary patent during opposition proceedings, although this issue certainly was raised by the Kingdom of Spain. ${ }^{51}$ It was noted before that the CJEU's reasoning in C-146/13 appears incomplete and evades some of the issues raised by the Kingdom of Spain. ${ }^{52}$ Nevertheless, the decision is binding and it follows that the CJEU seems to accept that after grant both UPC and EPO judiciaries evaluate the validity of unitary patents, in which situation consistency regarding the application of patentability requirements for biotechnological inventions cannot be guaranteed. ${ }^{53}$

In its second plea in law, the Kingdom of Spain submitted that Article 118 TFEU is insufficient legal basis for Regulation 1257/2012, since the Regulation does not provide measures for uniform protection and it does not specify the acts against which the unitary patent provides protection. The CJEU stated that Regulation 1257/2012 ensures uniform protection since for each unitary patent one designated national law applies to the territory of all participating Member States. ${ }^{54}$ The Court remarked that Article 118 TFEU 'does not necessarily require the EU legislature to harmonize completely and exhaustively all aspects of intellectual property law'. ${ }^{55}$ Thus in the Court's view, 'uniform protection' does not mean that protection has to be uniform for all unitary patents, as long as for each individual unitary patent that protection is uniform in the territory of all participating Member States: the applicable law may thus

49. Case C-146/13, Kingdom of Spain v European Parliament and Council of the European Union, EU:C:2015:298.

50. Ibid, paras 28, 29, 30, 31 .

51. Petition at no. 23: see W Tilmann, 'Spain's action against the EU Patent Package: arguments and counter-arguments in Case C-146/13' (2014) 36(1) European Intellectual Property Review 4, at 4; see also Opinion of Advocate General Bot in cases C-146/13 and C-147/13, Spain v Parliament and Council, 18 November 2014, paras 57, 58.

52. W Pors, 'The unitary patent package, the Court of Justice, Union law and a further response to the academics' (2015) Berichten Industriële Eigendom 134, at 136, 138.

53. Aerts, note 48 above.

54. Case C-146/13, note 49 above, paras 46, 47.

55. Ibid, para 48. 
vary per unitary patent. ${ }^{56}$ Given the fact that the judgement is binding and there is no further recourse, this is an important observation by the Court: it appears to accept that there is variation in protection within the new system and that different unitary patents on identical biotechnological subject-matter can afford diverging protection, as long as the protection afforded by each individual patent is uniform across the participating Member States. Apparently, in the Court's view, 'uniformity' means that each individual unitary patent provides the same protection across the participating Member States, but it does not seem to mean that consistent and invariant patentability criteria should be applied to identical biotechnological subject-matter in different unitary patents in the Union. Therefore it seems all the more important in practice for the separate judicial bodies involved to mitigate the problems of inconsistency by striving as much as possible for harmonized and coordinated decisions, and by finding sensible solutions - presumably even more so than in the present situation. ${ }^{57}$ Such coordination, though, has the odd consequence that the EPO decides also for non-Union states in line with developments in the Union: the EPO as a matter of course cannot differentiate in its decisions between Union and non-Union states.

In decision C-146/13, the CJEU has provided its interpretation of the term 'uniformity'. It appears from the reasoning of the CJEU in its responses to the pleas in law by the Kingdom of Spain that the situation of partial inconsistency and legal uncertainty regarding European biotechnological patents persists in the system introducing the unitary patent. It may be questioned whether this assists in undistorted competition within an important industrial sector of the internal market: after all the Unitary Patent Regulation was promulgated in the context of the proper functioning of the internal market.

\section{CONCLUSIONS - THE CONSEQUENCES OF A HYBRID SYSTEM FOR THE PATENTING OF BIOTECHNOLOGICAL INVENTIONS IN THE UNION AND A CALL FOR COHERENCY}

Patents play an important societal function and with respect to stimulation of scientific and technological advances and the competiveness of biotechnology industries within the Union, patents are a very important vector. The question whether a certain type of biotechnological invention is patentable or not - and if patentable, under what conditions - is of immediate importance for industrial developments in agriculture and medicine, and for the smooth operation of the internal market. ${ }^{58}$ The European patent system can be said to be based on a double-pillar structure in which the pillars are independent: namely the supranational Union pillar based on Union law and the intergovernmental European Patent Organization pillar based on the EPC as an international convention. ${ }^{59}$ This double-pillar structure plays an even greater role with respect to biotechnological patents, since biotechnology is the single technical field in which the patenting of inventions is governed by substantive rules of Union law. The two pillars differ widely with respect to constitutional principles of democratic

56. Pors, note 52 above, at 137.

57. Cf. Pors, note 52 above, at 136.

58. Directive 98/44/EC, note 1 above, Preamble 7; Regulation 1257/2012, note 4 above, Preamble 4; T Minssen and A Nordberg, 'The evolution of the CJEU's case law on stem cell patents: context, outcome and implications of case C-364/13 International Stem Cell Corporation' (2015) 5 Nordic Intellectual Property Law Review 493.

59. Baldan and Van Zimmeren, note 47 above, at 1531. 
legitimacy of their lawmaking procedures, adherence to the rule of law and separation of powers over organs and institutions. ${ }^{60}$ Yet together the pillars determine the patenting of biotechnological inventions in the Union, and the independent nature of the two pillars is reflected in the partial incoherence in decisions concerning the criteria for the patenting of biotechnological inventions.

\subsection{The consequences of variable application of patentability criteria}

In the Union, the Biotechnology Directive regulates the criteria for patenting of pharmaceutically and agriculturally important materials and processes. Notwithstanding this Directive, given the two pillars of the European patent system the patenting of biotechnological inventions in the Union Member States is not consistent in the sense that under all circumstances there is an identical application of criteria that determine what products and processes are patentable and what are not. Rather, the outcome appears to vary with the kind of organization that decides on the subject-matter: the EPO and its judiciaries that are not part of the Union legal system and as such are not bound by Union law, on the one hand; or Union Member State administrative organizations and their judiciaries that are bound to Union law and are able to refer questions to the CJEU, on the other hand. In this context, the UPC according to its founding agreement is defined as a court common to the Union Member States, and like the Benelux Court is consequently situated within the judicial system of the European Union. ${ }^{61}$

The introduction of the unitary patent is a very important initiative for patenting in the Union, but it would appear that the situation of legal uncertainty concerning biotechnological inventions continues in this new system. Possible inconsistencies in the application of patentability requirements to biotechnological inventions under the unitary patent system seem even to have been accepted by the CJEU in decision C-146/13 on the action for annulment of the Unitary Patent Regulation. It appears acceptable that variable or even contradictory outcomes of validity tests for identical biotechnological inventions are possible, depending on whether the fate of a unitary patent is decided on during an opposition procedure before the EPO, or a procedure before the UPC, since the problem raised of jurisdiction after grant of a unitary patent by both EPO and UPC judiciaries was not addressed by the CJEU. Claimed subject-matter in a unitary patent may be affected differently during an opposition procedure before the EPO than during a procedure before the UPC after appropriate referral of a question to the CJEU. Furthermore according to decision C-146/13, 'uniform patent protection' appears to hold only for each individual unitary patent in the territory of all participating Member States, and not among unitary patents. Yet, the unitary patent was introduced specifically in order to foster the functioning of the internal market and to ensure undistorted competition. ${ }^{62}$

There are two conceivable ways in which departing views by the two judicial systems may seriously hamper the legal status of a biotechnological unitary patent. In the first place, a unitary patent may be upheld during opposition procedures for reasons that are a violation of Union law. In this case there is a form of redress, and in yet

60. RJ Aerts, 'The legitimacy of patent law-making in Europe and the US - a tentative comparison' (2007) 38(2) International Review of Intellectual Property and Competition Law 165. 61. Agreement on a Unified Patent Court, note 39 above, Art 1; Opinion 1/09, note 6 above, para 82.

62. Regulation 1257/2012, note 4 above, Preamble 4; Agreement on a Unified Patent Court, note 39 above, first preamble. 
a subsequent procedure, the patent can be revoked during a procedure before the UPC. In the second place, a unitary patent right may be revoked during an opposition procedure in violation of Union law. In this case, in contrast, there would appear to be no form of immediate redress, and the patent right concerned is lost irrevocably. From a constitutional point of view, in the Union Member States the last word on the interpretation of Biotechnology Directive provisions and the concomitant validity of patents should be with the CJEU, but in practice a crucial, irrevocable decision can be made entirely outside of the Union legal order. Until decisions by the CJEU on the correct interpretation and application of specific provisions of the Biotechnology Directive have been issued, there is in the Union Member States no absolute certainty about the relevance of decisions by the Boards of Appeal of the EPO in the field of biotechnology, since the decisions by the EPO based on Biotechnology Directive provisions taken over in literal wording in the Rules of the EPC bear no authoritative purport according to Union law. ${ }^{63}$

Conceivably, there also may be confusion about the application of the very same Biotechnology Directive provision to different patents concerning identical subjectmatter, such as divisional patents within the same patent family. For instance, in the case where there is a parent and a divisional unitary patent in the same family regarding an essentially biological process for the production of plants, and the validity of one of the patents is challenged before the UPC, whereas the other patent is opposed, that would presumably mean that the UPC will apply the relevant Biotechnology Directive provision (Article 2(2) Biotechnology Directive) and may refer a question on its interpretation to the CJEU, while according to the decision by the Enlarged Board of Appeal in consolidated cases G 2/07 and G 1/08, the EPO ignores the same provision taken over in identical wording in the EPC (Rule 26(5) EPC).

\subsection{The necessity of cooperation between Union and non-Union judiciaries}

The action for annulment of the Unitary Patent Regulation and the constitutional issues raised by the Kingdom of Spain in case C-146/13 presented itself as an opportunity for the CJEU to elaborate in its decision on the functioning of the new unitary patent system in the Union. The reasoning in the decision, however, appears not to provide complete guidance, and it was noted before that the reasoning of the CJEU appears to cast limited light on the challenges ahead, ${ }^{64}$ and that important concerns of good governance in the European patent system appear to have been basically ignored. ${ }^{65}$ Moreover, the Court stated that the Treaty provision on which the Unitary Patent Regulation is based does not require the Union law-maker to provide complete and exhaustive harmonization of all aspects of intellectual property law. ${ }^{66}$ Apparently, it is left for the various components of the European patent system to establish the necessary uniformity and consistency within the system.

Given these observations, it becomes all the more clear that coordination between the two separate legal systems deciding on biotechnology patenting in the Union Member States is highly desirable to solve the outstanding problems and to ensure consistency in the application of the requirements for patentability. The issue of coherency between the two pillars of the European patent system plays a role already with regard to classic

63. Aerts, note 6 above.

64. Plomer, note 32 above, at 525 .

65. Baldan and Van Zimmeren, note 47 above, at 1563.

66. Case C-146/13, note 49 above, para 48. 
European patents, but becomes even more pressing with the introduction of the unitary patent. Such coordination is not a simple effort, however, since the two legal systems are fundamentally unrelated. For instance, even though all EPC contracting states decided to adopt the wording of the Biotechnology Directive into the Rules of the EPC, decisions by the EPO in line with judicial decisions of the Union legal system inevitably mean that they are forced upon non-Union states as well, which adds to the complexity.

The EPO stated on several occasions that it is a separate legal order from the Union, that it is not a member of the Union, and that CJEU decisions are not legally binding on the EPO or the Boards of Appeal. ${ }^{67}$ There is no guarantee that the EPO will always follow Union judiciaries, and when a right is lost before the EPO in violation of Union law, the right is lost irrevocably. It was noted before that a loss of rights by a decision of the EPO without access to further independent judicial review of this decision is not a matter extraneous to the Union, and such a state of affairs may be contrary to due process rights and the right to property according to the Charter of Fundamental Rights and the European Convention for Human Rights. ${ }^{68}$

Likewise, the CJEU in its decisions is not limited in any way by decisions of the Boards of Appeal of the EPO, and the CJEU will apply different methods of interpretation and sources of law. ${ }^{69}$ For instance, based on both Articles 2(2) and 4(1)(b) of the Biotechnology Directive there is no guarantee that the CJEU would exclude from patentability the same essentially biological processes of crossing and selection of plants as the Enlarged Board of Appeal identified in consolidated cases G 2/07 and G 1/08, and likewise, when asked to, and when the CJEU would find itself competent to address the matter, it is not certain either whether the CJEU would follow the Enlarged Board of Appeal in its consolidated decisions G 2/12 and G 2/13 in finding patentable plants (other than a plant variety) obtained by essentially biological processes. ${ }^{70}$ Also importantly, the Union law-maker might step in and regulate contrary to EPO practice: recently the European Parliament expressed its concern about decisions G 2/12 and G 2/13 by the Enlarged Board of Appeal of the EPO, and issued a Motion stating that plants and plant material obtained from essentially biological processes should be excluded from patentability. ${ }^{71}$ Here, the European Parliament and the EPO follow incongruent routes.

Despite the above observations, the EPO and the Boards of Appeal acknowledged the need for uniformity in harmonized European patent law, and it was stated by the EPO that CJEU judgments should be considered as persuasive and as elements to be taken into consideration. ${ }^{72}$ Whether 'persuasive' means that the EPO will unconditionally follow CJEU judgments under all circumstances is unclear. In its decisions on the patenting

67. Decision T 2221/10, note 11 above, reasons 38; Decision G 2/02, note 11 above, reasons 8.6; Prosecution file of EP 1948791, Communications of 16 July 2014 and of 26 August 2014. 68. Baldan and Van Zimmeren, note 47 above, at 1564; Interview of 29 October 2015 by JUVE with Prof. Dr Siegfried Bross, available at <http://www.juve.de/nachrichten/namenundnachrichten/nachrichtrecht/2015/10/epa-disziplinarverfahren-verwaltungsrat-und-battistellihandeln-ohne-rechtliche-grundlage $>$ (accessed 2 January 2016).

69. Cf. Minssen and Nordberg, note 29 above.

70. Decision in consolidated cases G 2/12 and G 2/13 (Tomato II and Broccoli II), EP: BA:2015:G000212.20150325, EP:BA:2015:G000213.20150325; a plant variety remains excluded from patentability.

71. Motion of the European Parliament of 17 December 2015, 'Patents and Plant Breeders' Rights', 2015/2981 (RSP).

72. Decision T 2221/10, note 11 above, reasons 39, 40, 42; Decision G 2/02, note 11 above, reasons 8.6. 
of human embryonic stem cells, the EPO and the Boards of Appeal mentioned the CJEU decision in the Brüstle case, and recently the Examining Division of the EPO has also aligned its practice to the $I S C C$ decision. ${ }^{73}$ Likewise, the CJEU in its Brüstle decision referred to an earlier decision by the Enlarged Board of Appeal on stem cell patenting. ${ }^{74}$ In general, there can be no doubt that Union Member States courts, on the one hand, and the Boards of Appeal, on the other hand, duly take each other's decisions into consideration and will consider them mostly relevant, albeit not binding. ${ }^{75}$ Ideally, the judiciaries are in concordance with each other for purely substantive and technical patenting reasons, and not merely for desirability of alignment or for the policy context. ${ }^{76}$ Given the quite brief explanation provided by the CJEU in decision C-146/13 about the exact functioning of the unitary patent system, unwanted inconsistencies with respect to biotechnology patenting can only be mitigated and sorted out by future harmonization efforts of all judicial bodies involved. ${ }^{77}$

\subsection{Incomplete control by the law-makers of the Biotechnology Directive}

Because the patenting of certain kinds of biotechnological inventions is a sensitive area, during the adoption of the Biotechnology Directive the European Parliament wanted to secure ethical issues. For this reason and due to political polarization, a first reading of the draft Directive was rejected by the Parliament, and only after the concerns of the Parliament were addressed could the Directive be issued. These ethical concerns are in particular regulated in Articles 5 and 6 of the Directive regarding the patentability, for instance, of uses of human embryos, the human body at the various stages of its formation and development, and elements isolated from it such as sequences or partial sequences of genes. ${ }^{78}$ In addition, the Directive sets rules for the patenting of agricultural processes and products. ${ }^{79}$

Due to the influence of the European Parliament, the adoption of the Biotechnology Directive has a solid democratic basis. It was the objective of the European Parliament and the Council to regulate and harmonize the requirements for the patenting of biotechnological inventions in the Union Member States. This objective, however, seems diluted by the fact that the organization actually granting classic European patents and unitary patents, and evaluating their validity during opposition procedures, is situated institutionally and judicially entirely outside of the Union legal order. ${ }^{80}$ In this context, it is important to note also that the European Parliament is a direct law-maker in the Union, but under the EPC system of law-making due to its intergovernmental character, a democratic element is largely absent and national parliaments are not actively involved in law-making. ${ }^{81}$

The field of biotechnology is the only technical field for which Union law provides specific rules for the patentability, or exclusion from patentability, of products and

73. Decision T 2221/10, note 11 above, reasons 44; Prosecution file of EP 1948791, Communication of 16 July 2014, para 10.3 .

74. Case C-34/10, note 15 above, paras $45,51$.

75. Baldan and Van Zimmeren, note 47 above, at 1550 and references cited therein.

76. Plomer, note 32 above, at 531; Baldan and Van Zimmeren, note 47 above, at 1555.

77. Cf. Pors, note 52 above, at 136 .

78. Schneider, note 3 above.

79. Directive 98/44/EC, note 1 above, Arts 2, 4.

80. Aerts, note 6 above.

81. Aerts, note 60 above. 
processes, and as such this body of Union patent law remains a singularity for this specific technical field. There was a serious need for this legislation. ${ }^{82}$ Since the European Parliament and the Council have acted as legislators, some form of control by the Union legal order over biotechnology patenting in the Union Member States seems appropriate. However, this control by the Union legislators seems incomplete and flawed due to the fact that the organization that grants patents in Europe - both classic European patents and unitary patents - is detached from the Union legal order. Harmonization will only be achieved by intentional, concerted action of the various judiciaries involved. The problems noted here concerning legal uncertainty and incomplete control by the Union law-makers over their own legislation regulating patentability requirements will re-surface each time in the future the European Parliament and the Council decide to impose rules of substantive patent law for a specific technical field in the Union.

82. Cf. Crespi, note 3 above. 